\title{
QUATERNARY DEFORMATION OF THE MAVROPIGI LIGNITE FIELD (WESTERN MARGIN OF PTOLEMAIS - KOZANI GRABEN, NW MACEDONIA, GREECE)
}

\author{
Diamantopoulos A. ${ }^{1}$, Dimitrakopoulos D. ${ }^{1}$, Fountoulis I. ${ }^{2}$ \\ 1 Public Power Corporation of Greece, Division of Mines, Dirachiou Str. 87, 104 43, Athens \\ dimfrat@yahoo.com, dei-teym@otenet.gr
}

2 Faculty of Geosciences, University of Athens, 157 84, Athens, fountoulis@geol.uoa.gr

\section{ABSTRACT}

The present study aims to analyse in details the tectono-sedimentary processes of the western borderline of the intra-continental graben of Ptolemais-Kozani in NW Macedonia, given the presentday mining activity of Public Power Corporation. Field studies in combination with drilling analysis revealed the extremely geometrical complexity of the sedimentary fill as the result of the recent Quaternary deformation. Bearing in mind, the recognition of left-lateral strike-slip component of movement in the western border fault zone-Mavropigi shear zone, the geometrical coincidence of the morphological shapes of the present-day morphology-of the top-of the bottom of the Pliocene earthy lignite sequence and of the sub-surface morphology of the pre-Cretaceous Pelagonian basement as well as the discovery of several reverse faults in the surrounding area have allowed us to accept the action of a composite Quaternary deformational pattern. For the first time in NW Macedonia, ductile-brittle type macrostructures (mega-anticlines) with NE-SW axis direction are confirmed, showing the simultaneous and progressive action of ductile and brittle deformation of all the geological formations of the western borderline, sedimentary fill and metamorphic basement. The aforementioned geometrical complexity and also the observed field structures strongly reveal the action of a rotational couple-type stress field in Ptolemais-Kozani graben, enclosed in the intraplate in-type deformation of NW Macedonia. In this framework, the occurrence of the extensional post-orogenic structures, which seems that they have been overestimated by previous researchers in the literature, is considered of secondary importance and constitutes part and expression of the complicated Quaternary tectonic structures of the sedimentary fill. This complex deformational pattern controls and also defines the spatial distribution of the lignite reserves in the Mavropigi Lignite Field with a southward increasing of them as well as causes regions with a composite or a simple post-orogenic geometry and evolution, directly reflected by the sub-surface geometry of the Pliocene lignite sequence. The aforementioned complicated geometry is of great importance, either for the planning and the future expansion of the Mavropigi Lignite Field in the western borderline, or for the better approach of the intra-plate deformational processes of Ptolemais-Kozani graben.

\section{INTRODUCTION}

The present work is associated with the survey of the deformation of the sedimentary fill in Mavropigi Lignite Field, the first part of the future Western Field of Public Power Corporation (PPC) in NW Macedonia. The whole attempt is based on detailed field observations and also in the data of the depth, including drillings, hydrogeological and geophysical data. The combination of the aforementioned methodologies and sections of the geosciences is really necessary and effective in regions of especial economical interesting. In the followings analysis, we have included and analyzed 580 primary drilling data of PPC for the surrounding area of the Western Lignite Field. The study area is located in the western margin of Ptolemais-Kozani graben, a very well geometrical and deep NW-SE directed tectonic graben (Diamantopoulos et. al. 2004), figure 1.

The observed geological formations are dissociated in the metamorphic basement, including the pre-Cretaceous Pelagonian metamorphic sequences and in the sedimentary fill of Plio-Quaternary 
age (PPC 1987). The pre-Cretaceous Pelagonian units contain the Triassic-Lias pelagonian marbles, which through a low-angle normal shear (detachment) zone, overly the pre-Alpine Pelagonian basement, composed of metamorphic foliated rocks, schists and gneisses.

The study of the recent deformation of the post-orogenic sediments of Ptolemais-Kozani graben has been completely based on the structural analysis of the observed brittle structures. The majority of the bibliographical data, such as Anastopoulos et. al. 1972, Pavlides 1985, Doutsos et. al. 1998, Mountrakis et. al. 1999, Pavlides 2003 assumed that the existence of a pure extensional regime from Miocene to present-day period is the dominant stress field. All the previous researchers emphasized to the existence of several normal brittle structures, including also active normal faults (Pavlides 1985, Mountrakis et. al. 1999). In the followings structural analysis, we present new data regarding to the post-orogenic deformation of the sedimentary fill and of the metamorphic basement, which conclude the very complicated Plio-Quaternary deformation of Ptolemais-Kozani graben as well as to the complicated character of the post-orogenic brittle structures.

The beginning of the geological research in Mavropigi Filed (Mavropigi-Pontokomi settlements) is dated since 1952 by professor Papastamatiou I. and Vetulis 1957/1958, who gave a reliable and analytic geological view of the lignite reserves in the western margin. A more systematic survey began in 1980 by PPC for the exploitation of this region and its addition in the active lignite fields of Western Macedonia. A detailed analysis of the recent brittles structures in the lignite fields of Western Macedonia was given by Pavlides 1985. Steenbrink 2001 studied the stratigraphic succession of the continenttal sediments in the surrounding area, adopting a Late Miocene age for the inintiall formation of Vegoritis-Ptolemais-Kozani graben. Recently, Diamantopoulos et. al. 2003 and Diamantopoulos et. al. 2004a analyzed the hydrogeological regime, emphasizing to the important role of the pre-Alpine metamorphic rocks in the internal parts of the graben and also described its composite morphotectonic structure and the present-day geometry of the sedimentary fill.

\section{STRATIGRAPHY \& GEOMETRY OF THE SEDIMENTARY FILL}

The sedimentary fill contains lacustrine and continental sediments of Plio-Quaternary age, which constitute the upper members of the sedimentary sequence of Ptolemais-Kozani graben. They seal the strongly deformed morphology of the basement (unified), burying several tectonic planes-contacts of the pre-Cretaceous Pelagonian structural units (Diamantopoulos et. al. 2003, Diamantopoulos 2004). The stratigraphic succession of the sedimentary fill contains, from the bottom to the top (PPC 1987):

- Clastic Formation II of Pliocene age, with sands, clay, marls, mudstones and psammites.

- Lignite sequence of the earthy lignite of Late Pliocene age, constitutes the basic exploitation unit. It includes the characteristic horizon of the fossil Neritina.

- Clastic Formation III of Late Pliocene age, constitutes a set of clastic sediments overlying the lignite sequence. It is composed by sands, clay and marls.

- Proastion formation of Early Pleistocene (Billaphraghian) age, overlies the former formation with a characteristic unconformity, the second one in the overall stratigraphic succession. It is composed by multimict conglomerates, psammites, clays and pelites. In addition, it is important its northwards dip direction in the northern side, near Proastion settlement.

- Alluvials of Holocene age, with recent lax deposits.

The sedimentary fill forms a westwards tilting monoclinic sedimentary sequence, showing the function of NNW-SSE directed rotational axis parallel to the graben's direction. The strong westwards increase of the thickness of the Quaternary sediments and of lignite sequence shows that strong syn-sedimentary deformation took place during the sedimentation in Plio-Quaternary, figure 6.

\section{BRITTLE DEFORMATION}

The present-day structural view of the sedimentary fill is characterized by the influence of recent and strong brittle-type deformation with the expression of planar and listric (gravity) normal faults as well as a large number of reverse faults, unknown until now, constitutes a very significant structural element. The brittle structures are separated in those who impact only in the sedimentary fill and in the most of the cases constitute syn-sedimentary brittle structures and also those who are associ- 


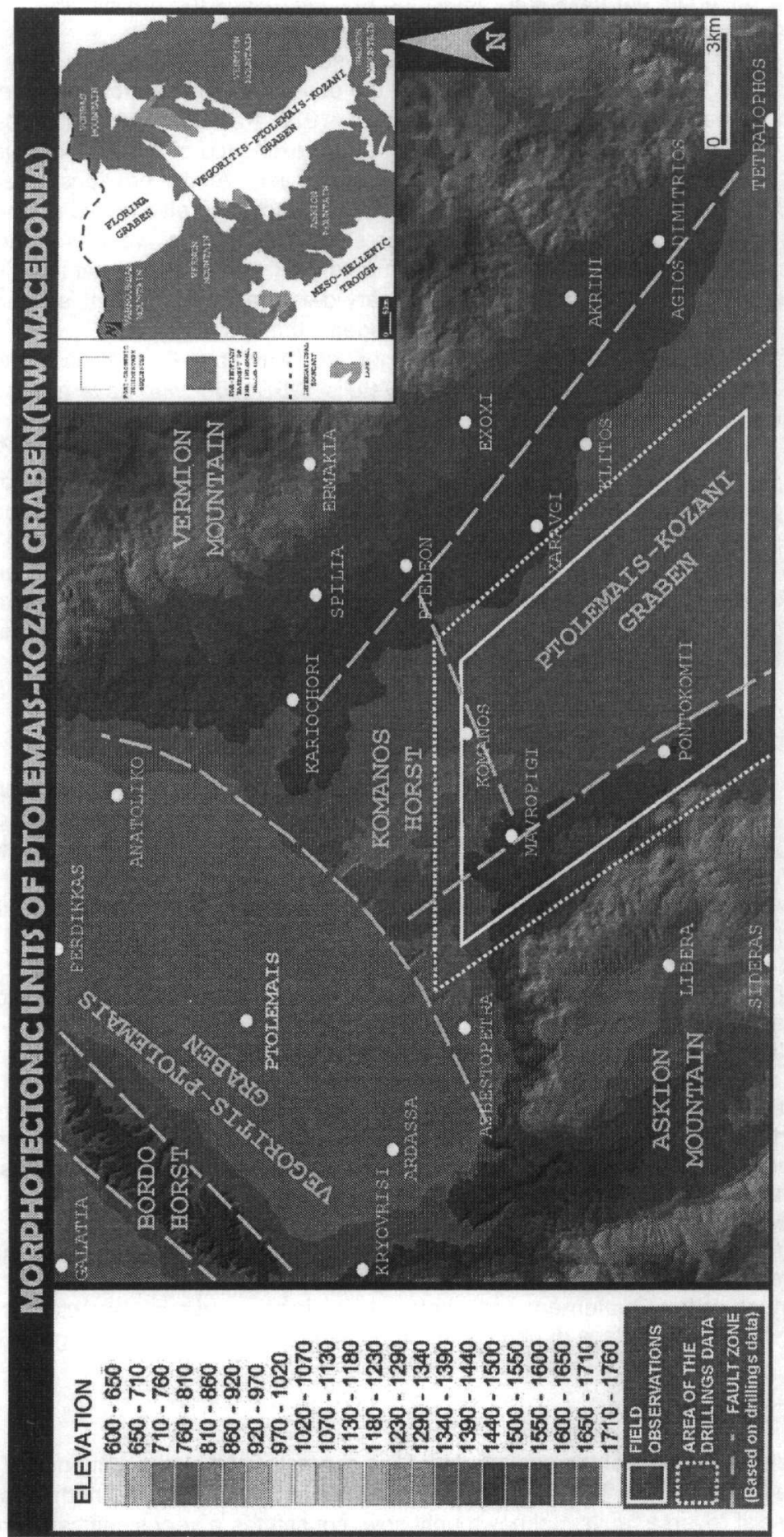

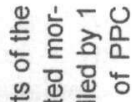

要造焉

ता

능죠 정

들 정 항

흠 항

후응

띻은음

둔

음 등 맹

क क

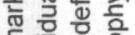

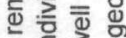

का $\leq 3$

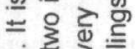

एक

등

N

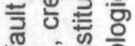

匹

๘

헝드

ส

里京焉

5. 뜬

네을

융 홍

흥 흔

훟ㄷㄴ

응 演它

है

흘르은

है

㺃

인

등 है

응 트

드 은 응

드름은

잉무

훙유

도 $\frac{\omega}{\pi}$.

N๊

뜬

는응. 눈

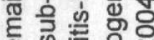

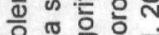
응 앵혀

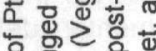
¿ 的蛇 山่ 뜨요 황 : $=$ 정을 Ф 으의 흐융을 응

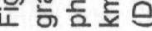



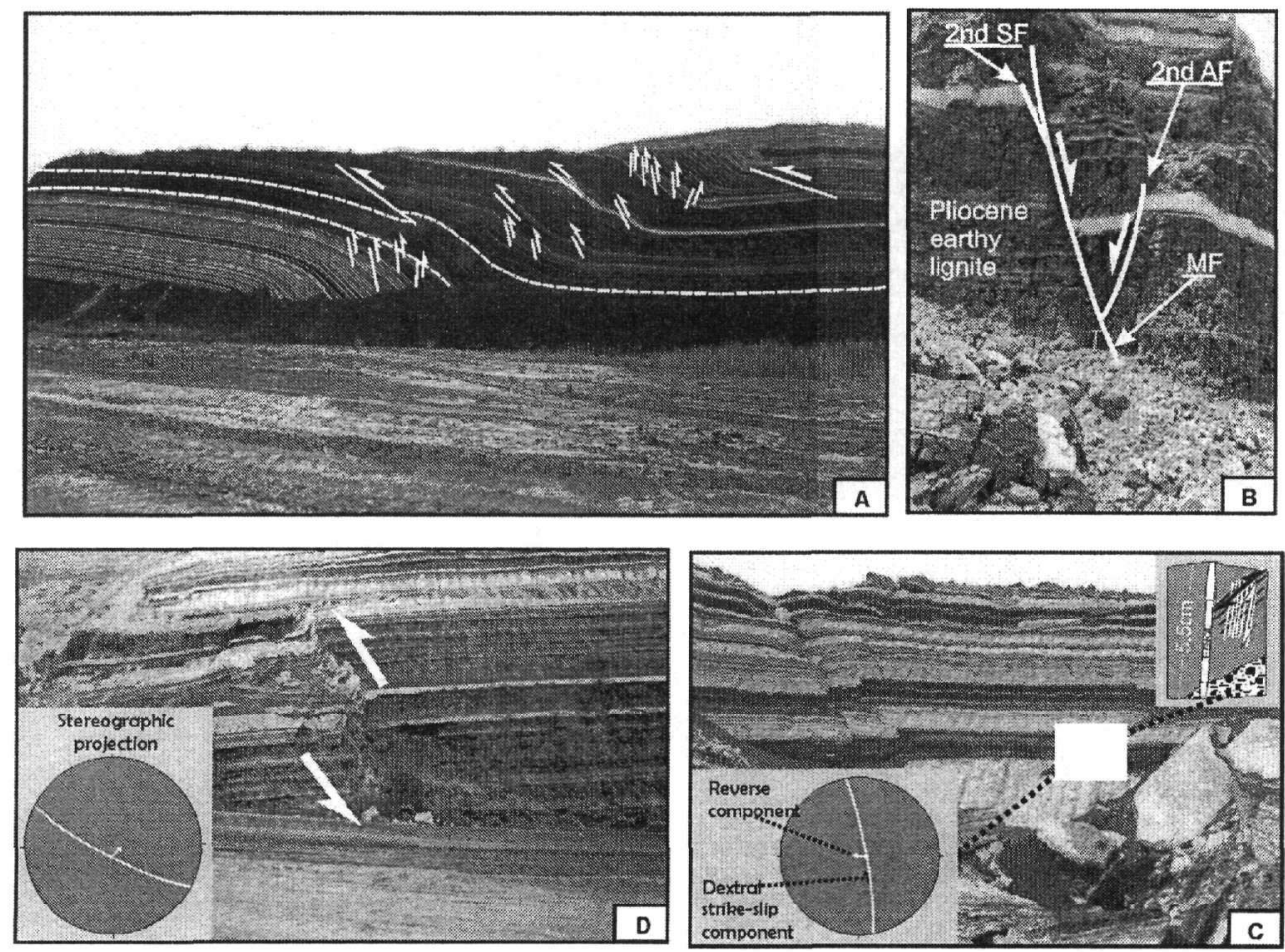

Figure 2. Syn-sedimentary growth faults of the sedimentary fill. A. Ductile-brittle macrostructure with reverse faults of the Pliocene lignite sequence, Kardia Mine. B. Rollover structure with a $2^{\text {nd }}$ synthetic (SF) and a $2^{\text {nd }}$ antithetic (AF) fault in Mavropigi Mine. C. Pop-up structure with high-angle conjugate reverse and dextral strike-slip faults in Komanos Field. D. Reverse fault in the lignite sequence of Mavropigi Mine.

ated with the tectonic evolution of the graben and essentially they are the fault surfaces of the western border fault zone-Mavropigi shear zone. According to our field studies, we confirmed dipslip vertical, dip-slip normal, oblique-slip normal, dip-slip reverse and oblique-slip reverse faults.

The presence of the brittle structures in the sedimentary fill is of great importance, either in the better knowledge of its recent brittle deformation, or in the stability of the slopes of the mines. Detailed field studies in all the mining units of PPC revealed the strong occurrence of reverse brittle structures, which play an important role with reference to the occurrence and the role of the compressional intra-plate structures and also they cause an apparent large thickness to the Pliocene lignite sequence, figure 2 . In many cases, they co-exist with gravity structures and constitute a major element of the brittle-type deformation, striking in general N-S direction. An interesting point is the frequent formation of pop-up structures within the mining units, presumably associated with intra-plate continental transpression and dextral strike-slip faults, figure $2 A-D-C$.

In parallel, the analysis of the fault surfaces of the western border zone-Mavropigi fault zone revealed that it constitutes a composite shear zone with re-activations in the recent geological past. Mavropigi fault zone strikes in NW-SE direction in Mavropigi-Pontokomi settlements, with an apparent false throw more than $300 \mathrm{~m}$ going basinwards and also it is cut by the Quaternary NE-SW directed Asbestopetra-Kariochori-Komnina fault zone (Papastamatiou 1952), near Proastio settlement. The set of the fault surfaces constitute a left- and right-stepping en echelon arrangement, cutting the Plio-Quaternary sediments. We observed, at least, two set of striations, the first and the dominant one showed an oblique-slip normal movement, which is combined with a left-lateral strikeslip component of movement and also a vertical set of striations of a clear normal sliding, figure 3. The aforementioned en echelon arrangement of the fault surfaces in combination with the strong 

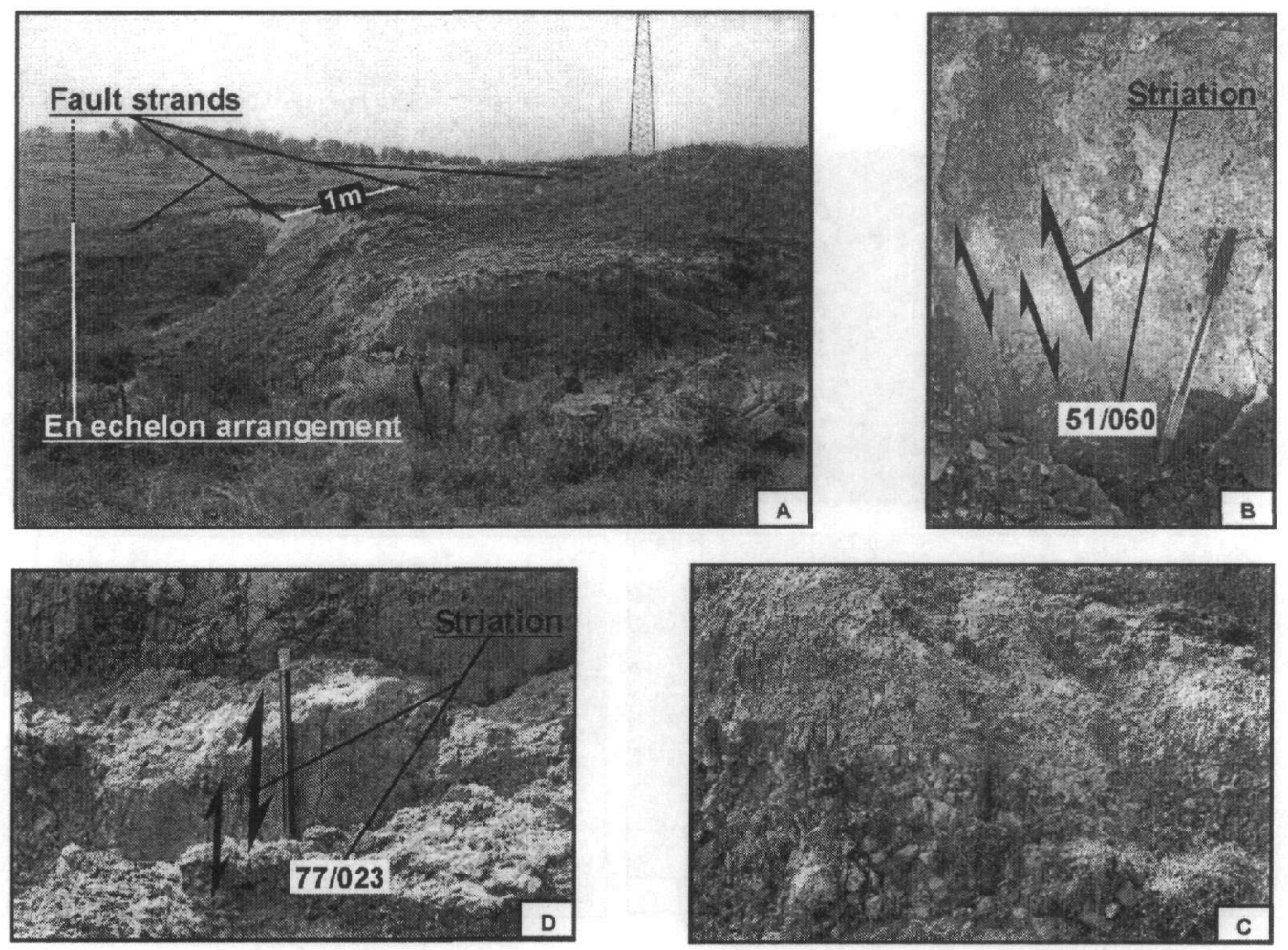

Figure 3. Field photos from the Mavropigi shear zone (MSZ). A. En echelon arrangement of the fault strands in Mavropigi settlement. B. Oblique-slip striation system, showing the dominant and left-lateral strike-slip character of the MFZ. C. Fault breccia in MFZ, rich in marble fragments. D. Vertical striation system.

westwards tilting of the sedimentary fill signal for the action of anti-clockwise horizontal rotational axis, parallel to the direction of Ptolemais-Kozani basin, defining $3^{\text {rd }}$ order three dimensional structures. Thus, according to the above field observations, it is clear the action of Mavropigi shear zone in Plio-Quaternary period, characterizing it as a possible active fault zone.

The significance of the above confirmations is the presence of compressional intra-plate deformation in the greater area, which co-exists with brittle structures of gravity character, included in the same time span. Thus, the study of the brittle structures outlined the complex character of the brittle tectonic structures with the presence of extensional, compressional and strike-slip deformation.

\section{DUCTILE-BRITTLE DEFORMATION}

The research of the ductile-brittle deformation mainly achieved by the analysis of 580 drillings of PPC in combination with field observations in the surrounding area of Ptolemais-Kozani graben. The following description of the ductile-brittle macrostructure of the western borderline constitutes the first example of Quaternary ductile-brittle type deformation in Western Macedonia.

For the better structural view of the lignite sequence, we constructed the $3 \mathrm{D}$ representation of its geometry. The 3D representation of the morphology of the present-day surface, of the top and of the bottom of the lignite sequence and of the pre-Cretaceous metamorphic basement have led us to determine a visible and clear mega-flexure (macro-fold) in the macro-scale, as schematically figure 4 represents. Its geometrical configuration is accompanied by the creation of two internal $3^{\text {rd }}$ order tectonic grabens, showing the simultaneous occurrence of brittle deformation inside this macrostructure, named hereafter as ductile-brittle macrostructure. The region, in which it is observed the 


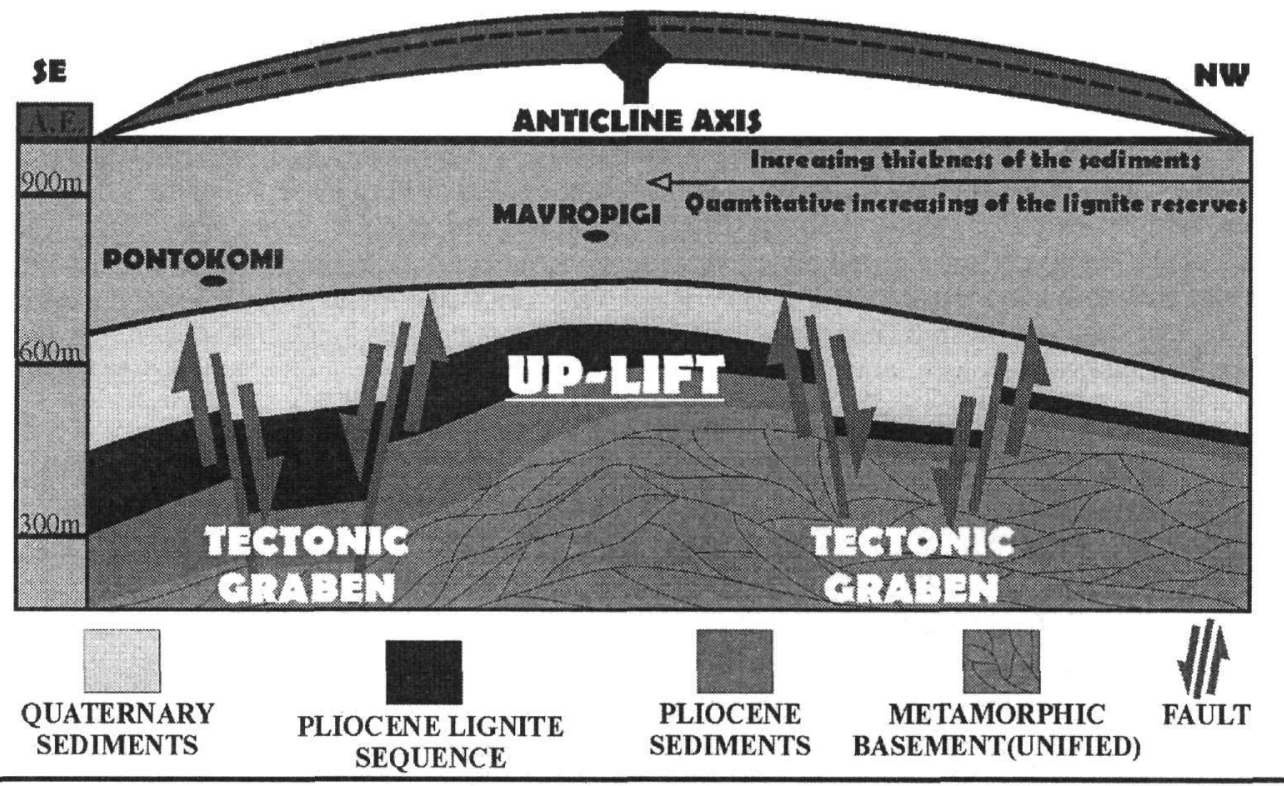

Figure 4. Schematic representation of the ductile-brittle macrostructure in the western borderline of PtolemaisKozani graben. In this illustration, they are taken into consideration 580 drillings data along the western margin. It is also noted the southwards quantitative increasing of the Pliocene lignite reserves with a homologous behavior of the thickness of the Quaternary sediments.

above mega-anticline axis coincides with the region of the presence of the relative up-lift motion of the metamorphic basement, as Diamantopoulos et. al. 2003 estimated. Thus, there is a possible relation between the up-lift motion of the pre-Cretaceous basement with the surface development of this macrofold. These ductile-brittle macrostructures seems to be combined with reverse faults, in Komanos Field, where simultaneously with an upper extensional part, there are in the lower parts of them compressional brittle structures, figure $2 \mathrm{C}$. This observation allows to be assumed that these structures constitute tangential longitudinal folds with an upper extensional part and a lower compressional part. However, according to the sub-surface data, this mega-anticline geometrical arrangement of the sedimentary fill is very well conserved, going from Mavropigi to Komanos settlement towards east. In addition, it should be noted that the above described macrofolds are the result of shallow deformational conditions, where the ductile deformation begins earlier and it is accompanied by the simultaneous action of brittle-type deformation in a secondary evolutionary stage of them. The key point of the aforementioned geometrical transformation is that the acted deformation is a continuous process during the geological time, which is also accompanied by a general rearrangement of the morphotectonic view and the geometry of the whole macrostructure.

In parallel, this recent Quaternary ductile-brittle deformation is also imprinted in the minor structures of the metamorphic sequences of the western borderline. Furthermore, all the minor folds, including isoclinal-tight-open-kinks folds, of the schists outcrops are presented in a stable NW-SE direction and they are dipping either NW or SE, following the similar geometrical orientation of the major mineral-stretching lineation $L_{n+1}$. A similar geometrical orientation but somehow slightly is also observed in the main secondary penetrative foliation-mylonitic texture $S_{n+1}$. This general megaanticline adaptation of the alpine tectonic fabric is also conveyed in the sub-surface geometry of the tectonic contact pelagonian marbles- pre-Alpine Pelagonian basement in Agios Markos hill, figure 5. Thus, their spatial distribution follows the formation of the former mega-anticline, undergone by the same recent deformation. 


\section{SUB-SURFACE MORPHOLOGY AND TECTONIC STRUCTURE}

The study of the sub-surface morphology and structure of the western borderline is based on 40 drillings of PPC, which cut the pre-Cretaceous Pelagonian basement. The representation of them in $3 \mathrm{D}$ dimensions revealed the morphology, the major sub-surface brittle structures and also gave new data for the geometrical development of the MSZ. We constructed two geological crosssections with a general NW-SE direction, parallel to the western borderline. In figure 5 , it becomes clear the formation of $3^{\text {rd }}$ order macrostructures of the pre-Cretaceous metamorphic rocks with the geometrical development of three dimensional tectonic horsts and grabens. The first cross-section corresponds to a tilted fault block arrangement with two clockwise rotated fault-bounded blocks and the second one to a basin \& range topography. In that case, the Pliocene unconformity of the sedimentary fill above the basement constitutes the basic element of the calculation of the displacement in the sub-surface fault zones.

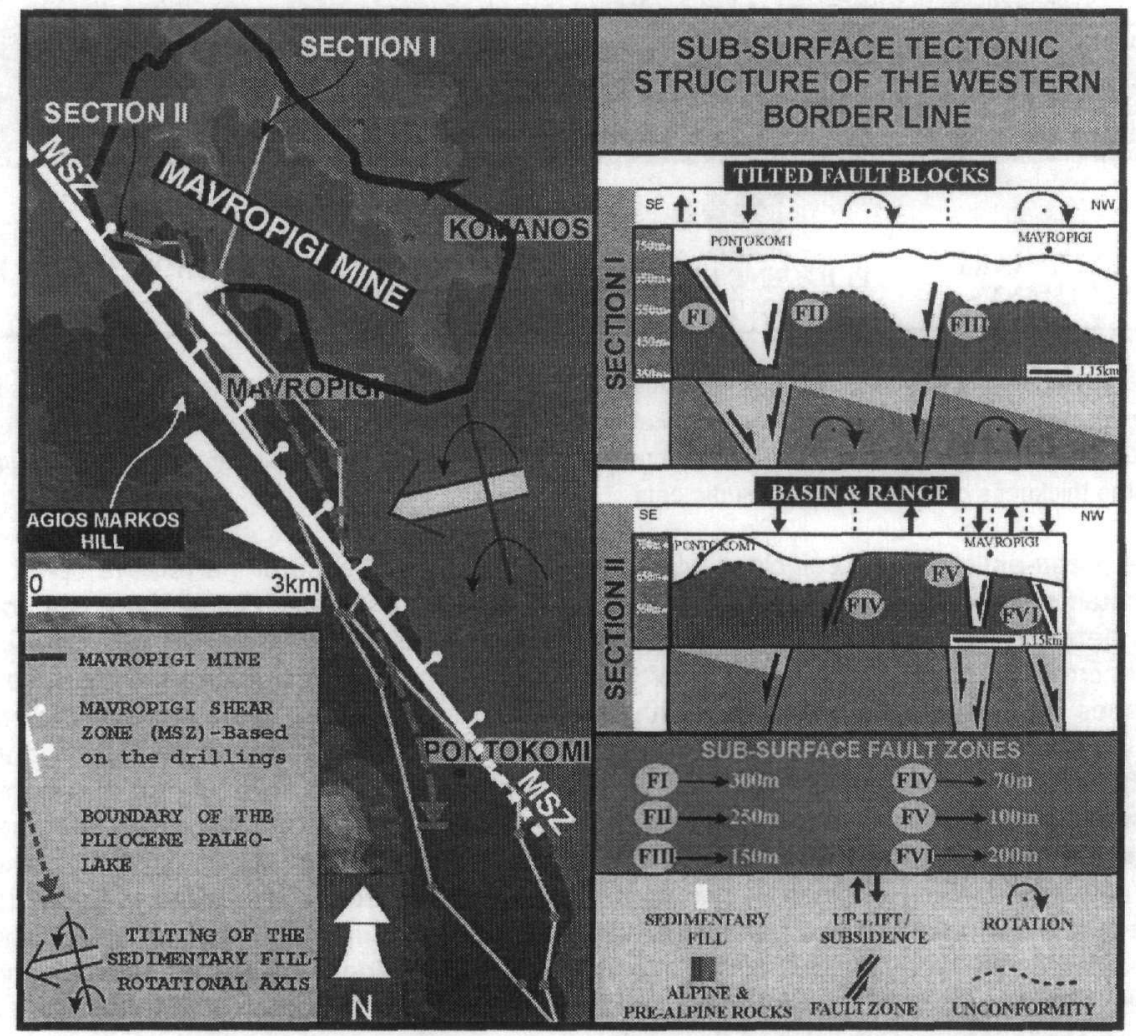

Figure 5. The sub-surface tectonic structure of the western borderline, emphasizing to the sub-surface geometry of the Mavropigi shear zone. The two geological cross-sections represent the sub-surface morphology of the pre-Cretaceous Pelagonian rocks. The numbers in the cycles correspond to the false throws of the major subsurface fault zones. In parallel, it is drawn the western boundary of the Pliocene paleo-lake.

Regarding to the Mavropigi shear zone, it became clear its fluctuated false throw along the margin and it was defined its detailed sub-surface arrangement, which essentially coincides with the geographical axis Mavropigi-Pontokomi settlements. The general sub-surface structure of the western borderline is also outlined, either by the significant occurrence of brittle structures with more than $300 \mathrm{~m}$ false throws or by the action of strong syn-sedimentary conditions during the sedimentation, showing that the progressive subsidence of the western borderline was achieved through many evolutionary stages. Notwithstanding, this peculiar geometry and deformation-type of the western borderline (Askion $\mathrm{mt}$.) is not observed in the homologous eastern borderline (Vermion 
$\mathrm{mt}$.) with the result, it is created a general dismemberment of the deformational processes in the greater area of Ptolemais-Kozani graben.

\section{CONSEQUENCES IN THE MINING ACTIVITY OF MAVROPIGI LIGNITE FIELD}

From figure 4 , it becomes obvious an increasing of the thickness of the lignite sequence in the southern part-Pontokomi settlement in contrast north of Mavropigi settlement, where it is observed a decreasing thickness of the same sequence. Thus, it is clear that the quantities of the lignite reserves in the southern part are larger than the homologous in the northern part.

The aforementioned mega-anticline macrostructure presupposes that in the region of the anticline axes they are determined the better exploitation conditions because of the relative up-lifted structural location of the lignite sequence. In addition, the fact that westwards the thickness of the sediments increases, it leads the external (western) boundary of the Mavropigi Mine closer to Mavropigi settlement. However, this westwards free displacement of the mine boundaries is strongly controlled by the morphology of the pre-Cretaceous metamorphic rocks with the result the distance between Mavropigi settlement and Mavropigi mine has to be planned in safe distance values. In figure 6 , it is illustrated the tectonic structure of the western borderline in Mavropigi settlement, showing clearly the location of the Mavropigi Lignite Field with reference to the complex geometry of the post-orogenic sediments and also the strong faulted sub-surface structure of the basement. In the same representation, we also note that the Agios Markos klippe (tectonic outlier of the pelagonian marbles) constitutes an isolated hydro-geological unit and only an insignificant inflow is expected towards Mavropigi mine or Plio-Quaternary sediments of the western margin.

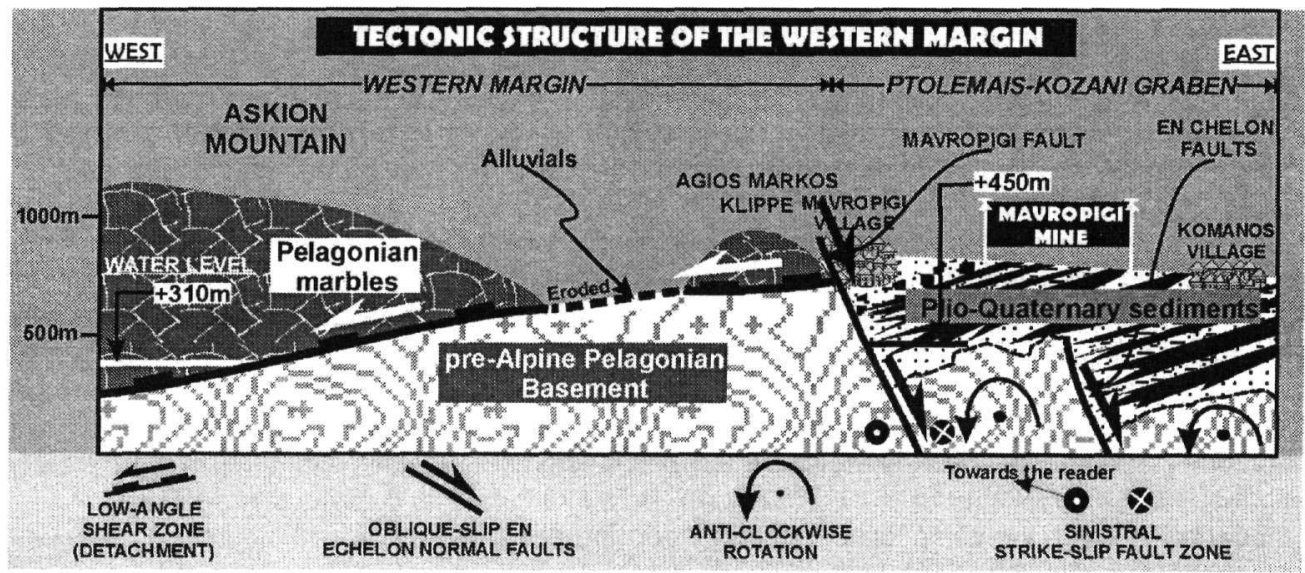

Figure 6. Schematic geological cross-section along the western borderline. It has been noted the westwards titling of the sediments, the en echelon arrangement of the MSZ, the anti-clockwise rotation of the sediments and also the nappe-structure of the pre-Cretaceous Pelagonian sequences.

In addition, the interrelation of the sub-surface data, in the most of the cases leads to the recognition of the sub-surface brittle structures but in any case this determination should not be applied for the recognition of their kinematic character. Several examples from our field studies in the mining units of PPC corroborate the above assumption, which frequently is used as a working hypothesis with the acceptance of the gravity character of the tectonic structures, ignoring the great complexity of the brittle-type deformation. Furthermore, in the cases where the sub-surface data indicate the existence of a strong sub-surface brittle structure with the basement-involved, contrasting different lithological groups and also it is accompanied by a normal and reverse-separation faults in the lignite horizons (top-bottom), it is concluded the action of strike-slip faults affecting all the geological formations, flower structures (Allen et. al. 1990). 
The future exploitation of the lignite reserves of the Western Field should take into consideration these data, in order to define the boundaries of the mine and also the depth of the exploration. In parallel, the aforementioned analysis is of great importance for the determination of the groundwater divide (watershed) along the western borderline between the two separated hydrodynamic systems of the pelagonian marbles in the greater area. The northern hydrodynamic system $(+520$ a.s.I.)-HDS I is not expected in our study area given that the pre-Alpine Pelagonian basement is uplifted, creating an impervious sub-surface zone (Diamantopoulos et. al. 2003). Furthermore, the mine area is influenced by the southern hydrodynamic system-HDS II (+310a.s.I.), which does not impact the study area, given that the bottom of the Mavropigi Field is planned at the $450 \mathrm{~m}$ a.s.I.

\section{CONCLUSIONS-DISCUSSION}

From all the aforementioned, it is concluded that the Quaternary deformation of the western margin of Ptolemais-Kozani graben and essentially the homologous processes in the surrounding area are hardly complicated. The contemporaneous development of normal faults (with or not strike-slip component), of reverse faults (with or not strike-slip component) and of a mega-anticline macrostructure, either of the described surfaces (relief morphology, lignite sequence and metamorphic basement) or of the already arranged alpine structures, constitute the major criteria of the aforementioned assumption. Consequently, the deformation in the surrounding area of PtolemaisKozani graben is expressed by brittle structures of gravity and reverse character and also at the same time by ductile-type macrostructures. The suggested term "ductile-brittle macrostructure" for the aforementioned mega-anticline structure with a NE-SW axis direction in the study area includes the simultaneous and progressive action of ductile and brittle deformation, affecting all the geological formations, sedimentary fill and basement. Its temporal function and geometrical transformation is depended on the lithological heterogeneity of the involved formations. This described complex geometrical arrangement of all the geological formations is also accompanied by a strongly faulted sub-surface structure and morphology. The formation of tilted fault-bounded blocks and also the configuration of successive horsts and grabens constitute the major geometrical and structural characteristics of the western borderline of Ptolemais-Kozani graben. In addition, this sub-surface geometry also contains fault zones of large false throw, which control, either the sub-surface morphology of the basement (unified) or the spatial distribution of the sedimentary fill. A remarkable point of the aforementioned brittle structures is the formation of reverse or oblique-slip reverse faults (dextral strike-slip faults), which are directly associated with pop-up structures, showing either the strong occurrence of compression or the significant involvement of strike-slip component, presumably related to intra-plate transpression. The latter seems to be conveyed in the overall sedimentary fill and probably reveals the existence of syn-sedimentary strike-slip faults in a progressive deformational stage (Schreurs et. al. 2002), creating a strong faulted sedimentary sequence.

Bearing in mind, the complicated geometry and the peculiar tectono-sedimentary processes of the post-orogenic sediments (ductile-brittle deformation), the frequent arrangement of pop-up structures with oblique-slip reverse faults as well as the strike-slip kinematic character of the Mavropigi shear zone, it is concluded the action of a complicated deformational pattern, a rotational coupletype stress field in Quaternary period, as its multi-complex characteristics were analyzed by Mariolakos et. al. 1989. In this framework, the deformation-type is of ductile-brittle character with complex tectonic structures, which can be interpreted only by the acceptance of this peculiar stress field. Its progressive action is responsible for the complicated deformation of the sedimentary fill, controlling the spatial distribution of the lignite reserves and causing a dismemberment of the deformation along the overall graben, creating geographical regions with an extremely complex (western borderline) or with a simple evolution and geometry (eastern borderline). The assumption of previous researchers for the action of a pure extensional stress field simplifies the observed tectonic structures of the sedimentary fill, given that its presence is only apparent. These new structural data reveal and also corroborate the importance of the back-arc compressional intra-plate deformation in Western Macedonia, which has also been outlined by recent GPS data and field observations (Lekkas et. al. 1999, Sakellariou et. al. 2001, Fountoulis et. al. 2000, Fountoulis et. al. 2002, Diamantopoulos et. al. 2004a, Diamantopoulos 2004b). Furthermore, according to the above structural analysis the post-orogenic deformational processes of all the geological formations char- 
acterize a continuous and not a discontinuous process in the space-time, even in the upper brittle zone of the crust.

In conclusion, apart from the above theoretical conclusions and new ideas, the aforementioned composite deformational mechanisms appear important consequences, either in the spatial distribution of the lignite reserves with a specific geographical distribution along the western margin, or in the future geographical expansion of the Mavropigi Lignite Field. The detailed mapping of the surface and sub-surface geometry of all the geological formations constitute a basic determined factor before the exploitation of the lignite reserves for the better exploitation and the estimation of the hydrogeological behavior of the sediments and of the basement (Dimitrakopoulos et. al. 1993).

The first author D.A. is really grateful to Mr Chatzisabbas K., Mr Roubos Ch., Mr. Makris, Mr. Tsakiris N., Mr. Nikou A., Mr Barbas T. and Mr. Simeonidis M. for their valuable advice and help.

\section{REFERENCES}

Allen P. A., Allen J. R., 1990. Basin Analysis. Principles \& Applications. Blackwell Science, pp.451.

Anastopoulos I.Ch., Koukouzas K.N., 1972 Economic Geology of the Southern Part of Ptolemais Lignite Basin. Geol. Geoph. Res., (1972), No1.

Diamantopoulos A., Dimitrakopoulos D., 2003. The use of G.I.S in clarifying geological-hydrogeological conditions: The case of Ptolemais Basin. $2^{\text {nd }}$ Int. Conf. Ecol. Protect. Planet Earth. Sofia, Bulgaria. pp. 334-341.

Diamantopoulos A., Dimitrakopoulos D., 2004a. The morphology and the sub-surface structure of the preTertiary basement of Ptolemais-Kozani graben (NW Macedonia, Greece). $7^{\mathrm{TH}}$ Panhellenic Geographical Congress of the Geographical Society of Greece, volume I, pp. 415-422.

Diamantopoulos A., Dimitrakopoulos D., 2004b. Intra-plate tectonics in Western Macedonia (Northern Greece): Quaternary macrofolds and deformational pattern of Ptolemais-Kozani graben. International Symposium on Earth System, Istanbul, Turkey, pp. 589-598.

Dimitrakopoulos D., Louloudis G., Koumantakis I., 1993. The impacts of the drought on the aquifers of the PlioQuaternary sediments in Ptolemais basin (N. Greece). $2^{\text {nd }}$ Hydrogeological Congress of the Hellenic Hydrogeological Committee, Patra city.

Doutsos Th., Koukouvelas I., 1998. Fractal analysis of normal faults in Northwestern Aegean area, Greece. J. Geodynamics. Vol. 26, No 2-4, pp. 197-216.

Fountoulis I., Kranis H., Lekkas E., Lozios S., Skourtsos M., 2000. Quaternary deformation in Grevena Basin (W. Macedonia, Greece): Importance of Shear and Compression. Annales Geologiques des pays Helleniques, vol. XXXVIII, pp. 123-132.

Fountoulis I., Paradissis D., Veis N., Tsagaroulias B., 2002. Recent movements of the upper crust due to creep deformation based on GPS measurements in W. Macedonia (NW Greece). $11^{\text {th }}$ General Assembly of the Wegener Project 2002, Athens, Greece.

Lekkas E., and others 1999. Neotectonic Map of Greece, Sheet Grevena, Scale 1:100.000. E.P.R.O., University of Athens.

Mariolakos I., Fountoulis I., Logos E., Lozios S., 1989. Methods to study the torsional neotectonic deformation: the case of Kalamata area (SW Pelloponesus, Greece). Proc. $4^{\text {th }}$ Congr. On Regional Crustal Stability and Geological Hazards, IGCP Project 250, pp. 15-21.

Mountrakis D., Kilias A., Pavlides S. and others, 1999. Neotectonic Map of Greece. Sheet: Kozani, Scale 1:100.000. E.P.P.O, University of Thessaloniki.

Papastamatiou I., 1952. Geological survey on the Ptolemais lignite basin. Geological and Geophyical Surveys, I.G.S.R.

Pavlides S., 1985. Neotectonic evolution of the Florina-Vegoritis-Ptolemais Basin (W. Macedonia, Greece). PHD Thesis, University of Thessaloniki, pp. 265.

Pavlides S., 2003. Geology of the earthquakes. Introduction to the Neotectonics, Morphotectonics and Paleoseismicity. University of Studio Press, pp. 378.

PPC., 1987. Economic Geology in Diavolorema-Mavropigi-Pontokomi region of Ptolemais lingnite basin. Kefalas S., Diamanti-Xiropoulou I.

Sakellariou D., Rousakis G., Kranis Ch., Kamperi E, Georgiou P., Skoulikidis N., 2001. Neotectonic movements, sedimentation and water-level fluctuation of the Lake Vegoritis in Upper Quaternary. Bull. Geol. Soc. Greece. vol. XXXIV/1, 207-216.

Steenbrink J., 2001. Orbital signatures in lacustrine sediments. The Late Neogene intramontane FlorinaPtolemais-Servia Basin, Northwestern Greece. Geologica Ultraiectina, No. 205, pp. 167.

Schreurs G. S., Colleta B., 2002. Analogue modeling of continental transpression. J. Virtual Explorer, 6, 67-78.

Vetulis D., 1957/1958. Beitrage zur Kenntnis der Geologie des Ptolemaisbeckens (Makedonien). Ann. Geol. Des Pays Hell. VIII-IX, 48-79. 